\title{
How Capitalism Creates Peace in Don Quixote While Non-Capitalism Induces Violence
}

\author{
Emre Gurgen \\ Independent Scholar, Germantown, Maryland, U.S.A.
}

\begin{abstract}
This article reasons that free-market capitalism produces peace in Don Quixote while its absence induces violence.

Specifically, it shows readers: that when Don Quixote's characters inherit peace transpires but when they are extorted gore happens; that a modern salary causes peace in Don Quixote while a feudal Mercedes causes conflict; that when contracts are honored Don Quixote's characters are calm but when contracts are breached its' characters are violent; that figures in Don Quixote who work for a living are tranquil while those who do not work fight; that peaceful capitalism in Don Quixote is separate from, and better than, violent corsair anti-capitalism; that Capitalism's profit motive does not cause slavery in Don Quixote but feudal suppression of human freedom does; that peaceful economic justice is adjudicated by civil judges, such as Sancho Panza, while bloody economic injustice is inflicted by either vigilantes (in Don Quixote's case) or monarchical brutality (in the Holy Brotherhood's case); and penultimately, that when the novel's financial disputes are decided by law courts peace ensues but when they are not violence happens.

Finally, this article finishes, by enumerating specific areas of future research on capitalism in Don Quixote.

Scholars interested in Emre Gurgen's full scholarship, can visit his personal author website at www.don-quixote-explained.com

Keywords: capitalism in Don Quixote, free markets in Don Quixote, economics in Don Quixote
\end{abstract}

\section{Introduction}

Though a number of recent studies focus on the importance of economic terms and concepts in Don Quixote, most notably Johnson's Cervantes and the Material World and Quint's Cervantes's Novel of Modern Times, these books, as well as disciplinary debates on the novel, do not show how free market capitalism creates peace in the book while lack of laissez-faire induces violence. Therefore, to fill this research gap, I argue that when non-capitalism is practiced in Don Quixote peace decreases but when capitalism is adopted peace increases.

Specifically, I reason that when the book’s government violates capitalism by stealing its Moriscos money, Spaniards fight. But when it upholds capitalism by allowing its' characters to inherit no violence occurs. Next, I turn to the idea that when Don Quixote and Sancho Panza's relationship is based on a feudal Mercedes (or sporadic gifts) for services violence ensues but when their relationship is based on a capital salary (or fixed wages) for jobs peace transpires. I then link peace and violence in Don Quixote to the fulfillment or violation of 
capital contracts by showing readers that characters befriend or fight each other when financial agreements are honored or broken. Fourth, I show readers that to the degree that Don Quixote is based on capitalism its characters are able to rise socioeconomically by taking honest commercial jobs in an honest commercial world while to the extent it is based on non-capitalism, specifically feudalism, unproductive parasites, like Barataria's knifer, try to violently steal people's money to survive.

Next, I question the communist claim that capitalists are exploiters by distinguishing creating capital honestly (exemplified, most notably, by the innkeeper's industry) differentiated from extorting other people's capital dishonestly (demonstrated, most obviously, by the novel's various bandits and pirates). I then decouple modern capitalism from feudal slavery by not only arguing that Sancho Panza's desire to peddle African slaves contradicts capitalism's axiom of a free labor force-mobile individuals who are most efficient and most productive when they work for their own gain not under the crack of a whip-but I also show that Sancho Panza's yearning to be a slave master stems from his desire to gain a title and live a cushy life ${ }^{1}$ not because he wants to earn money through real work.

Next, I claim that, on the one hand, peaceful capitalism and a secular judiciary flow together in Don Quixote (i.e. when Sancho Panza adjudicates debt disputes, loan repayments, and contractual disagreements during his governorship of Barataria) but that violent non-capitalistic looting also manifests when Don Quixote plunders other people's goods. By connecting Sancho Panza's secular judgeship with peace, on the one hand, then linking Don Quixote's robbing with anti-capitalism, on the other hand, I not only illustrate that an objective judiciary is used in the book to reinforce the principles of capitalism, I also show that the novel's characters appeal to law courts, not feudal lords, to resolve their fiscal differences. Lastly, I argue that needless violence is created in Don Quixote when there is no local economic court independent of the monarchy to adjudicate fiduciary loans.

\section{The Moriscos Non-Capitalistic Expulsion Causes Violence}

To explain why part of Don Quixote's violence comes from extorting the Moriscos private-property (i.e. their homes, stores, businesses, and money) then banishing these innocents to places such as Germany, France, Africa, and Turkey, it is vital to understand who the Moriscos were, how they contributed to Spain's economy, why many jingoistic xenophobes hated the Moriscos, and how Spain suffered economically because they ejected these former Muslims. Only after comprehending the Moriscos will you fully understand why their expulsion causes gore in Don Quixote.

To explain, the Spanish Moriscos were African Muslims who converted to Catholicism to stay in Spain. In the 1500's they numbered 50 to 60,000 strong, and grew to over 300,000 in 1610. Primarily, they were agricultural workers in Aragon and Valencia, "a considerable portion of which [tilled the land] on the estates of lay and ecclesiastical land owners” (Elliott, p. 278). Besides being a rural labor force, the Moriscos were also food producers and distributors, who worked in industries related to the trading, contracting, and "provision of foodstuffs: such as storekeepers, stewards, bakers, butchers, [pie-makers,] vegetable gardeners, water sellers, [and] tavern keepers" (Garcia, p. 167). In January of 1609, just before their expulsion in April of 1609, there were some 135,000 Moriscos in the cities and towns of Valencia, most of whom lived off their own labor as grocery store owners. Unlike their Valencian brethren, the "Castilian Moriscos [had] drifted to the towns [of La

\footnotetext{
${ }^{1}$ As Graf explains, "a fundamental aspect of the transition from feudalism to bourgeois capitalism involved an awareness that we should compensate people for their property or services.” (Graf, Five Free-Market Themes in Don Quijote, p. 2).
} 
Mancha] to take up fairly menial occupations, as carriers, muleteers, and small craftsmen” (Elliott, p. 306). In the port-city of Seville, for instance, some 7,000 Moriscos worked modest yet indispensable jobs as stevedores, carriers, and dockyard hands, while in Andalusia they took humble jobs as porters and cord makers.

As a direct result of a weak Spanish monarchy "anxious for easy popularity at a time of widespread national discontent," the expulsion of the Moriscos was carefully prepared and executed between 1609 and 1614 in accordance with King Phillip the II's April 9th 1609 order (Elliott, p. 305). Carried out by his subordinate, Don Bernardino de Valasco (the Count of Salazar) the expulsion saw the eviction of 270,000 2 Moriscos from a total Morisco population of slightly over 300,000. Since many Spanish reactionaries despised the Moriscos, the Crown ejected them from Spain.

Essentially, many Old Christian Spaniards blamed the New Christian Moriscos for: taking their jobs; cornering the agricultural labor market; occupying the best places in towns and cities; working fertile lands; hoarding their money; conspiring with the Ottoman ${ }^{3}$ Empire; and hatching plots with the Barbary pirates.

Regarding job loss, many Spaniards believed that the Moriscos took "good jobs" away from lower and middle-class Christians by either humbling themselves to the most "dirty” tasks, such as those of a farm laborer, or by becoming higher-paid merchants and traders. Many Spaniards also hated the Moriscos because they believed that they stagnated the local and national economy by saving their wealth, not spending it, by failing to put their money back into circulation as many Old Christians $\operatorname{did}^{4}$. Another reason why many Spaniards detested the Moriscos was because they thought that they lowered their standard of living by not only "retiring their wealth from circulation; [but also by] refusing to spend a single real on consumer goods [and services]" (Johnson, p. 57). In sum, the Moriscos were "disliked by many Old Christians for spending too little, working too hard, and breeding too fast” (Elliot, p. 306). In a word, for underconsuming, underdemanding, being too industrious, and procreating rapidly.

Because of their xenophobia, Spain stalled its economy in five main ways.

The first economic detriment of the Morisco expulsion was a "great decrease in trade and commerce because many of [the Moriscos] were in business and were useful because they tilled the land and worked other trades” (Dominguez, p. 204).

The second economic detriment of the Morisco expulsion was a labor shortage in the agricultural sector, since there was not enough Spaniards to work the nation’s extensive lands.

\footnotetext{
${ }^{2}$ Egginton confirms this number by writing that "between the time of the decree and 1614, the government systematically carried out the expulsion, forcing some two hundred seventy thousand of the estimated three hundred thousand remaining Moriscos to leave their homes and lives behind them to embark for North Africa, [where] countless would die of hunger or exposure or by violence at the hands of unwelcoming natives.” (p. 159).

${ }^{3}$ Many Spaniards feared an Ottoman-Morisco conspiracy since the Moriscos and the Ottomans both practiced Islam and both based their economies on agricultural labor. This idea is backed by Egginton's claim that the Moriscos "were widely suspected of sympathizing with the Turkish Empire and of abetting the Barbary pirates as they raided Andalusian seashore villages in search of captives to take back to Algiers as slaves.” (p. 159).

${ }^{4}$ Part of the reason, as Graf suggests, why the Moriscos withdrew their money from general circulation was to preserve their wealth, since the Spanish government often "ordered commoners to turn in their purer gold and silver coins in exchange for coins that [were] either debased with higher copper content or re-stamped with a higher face value” (Graf, Gresham's Law, p. 166). Thus, to avoid the robbing of their wealth by monetary debasement, many Moriscos saved good money and avoided bad; just like other "market participants secreted away good money as a store of value against the adulterated coins produced by the Hapsburg" Monarchs (i.e. King Phillips the II, III, and IV) (Graf, Gresham’s Law, p. 177).
} 
The third economic detriment of the Morisco expulsion was the "stillbirth of a native bourgeois capitalism [i.e. a middle class ${ }^{5}$ capitalism] grounded in [the] values and ideals that triumphed in Northern Europe" (Johnson, p. 61).

The fourth economic detriment of the Morisco expulsion was the loss of population, which translated into a loss of tax revenue for the crown, since the secular and ecclesiastical dues that the Moriscos paid disappeared along with the expelled Moriscos themselves.

The fifth economic detriment of the Morisco expulsion was the illegal export of capital, especially gold and silver coins, which shrank the money supply.

In sum, the Morisco expulsion undermined Spain's economy by: diminishing the flow of goods and services circulating in Iberia's economy; opening more jobs (notably in agriculture) than could be productively filled; decreasing the Monarchy's tax revenues along with the churches tithes; and shrinking Spain's Middle class to the point where the country split in two. Besides this, the Morisco expulsion also dried-up Spain's liquidity (by forcing capital to flee Spain), undercut Spain's source of cheap labor (especially when Iberia needed it the most), and, most importantly, disrupted production in labor sectors (such as agriculture) where Moriscos were primarily employed.

Evidently, the contraction of Spain's money supply is dramatized in Don Quixote by "Ricote's [real-life story, which is a fictional] representation of a typical Morisco economic profile as it emerges from the documentation: a tender (shopkeeper) in that nameless 'lugar de la Mancha' who has sneaked back into the country to recover his accumulated wealth” (Johnson, pp. 58-59). Since Spain's government unjustly seizes Ricote's private property (i.e. his store and home) he tries to preserve his remaining capital by converting his savings into "pearls and gems of great value, [and] money in the form of gold cruzados and doubloons, [which he then] buries in a [secret] hiding-place" (p. 922). Ricote's buried treasure is important because by "hiding the wealth [he] could not export [he] denies it to the Old Christian authorities" thereby diminishing Spain's economic power (Johnson, pp. 61-62). Thus, to recover his wealth Ricote dresses as a European Christian pilgrim, so he can dig-up, and smuggle out, the balance of his buried treasure. In order to live comfortably abroad Ricote secrets, "in the hollow of [his] staff [and in] the patch [of his] cloak over 100 escudos—-[riches Ricote has] saved [and] converted into gold despite all the precautions taken in the custom-houses where money has to be declared” (p. 855). Similarly, other Moriscos also preserved their wealth in this way by "smuggling relatively large sums of accumulated capital out of the country," primarily by mixing gold coins with dried fruit and exporting it to Turkey (Johnson, p. 62). And, though, on 24 February 1571 the monarchy declared that all "money, gold, silver, and jewels buried, covered over, hidden or otherwise concealed in diverse parts and places of [the] kingdom" must be returned on pain of death: serious money, despite this threat, in clandestine treasure, was smuggled across the border by Moriscos like Ricote (Dominguez, p. 210). Basically, the Morisco exfiltration of the nation's riches shows readers that Spain undermined its ability to form capital because it expelled its' Moriscos. And, because the Moriscos fled Spain with their money, there was less currency in the country to invest, which, in turn, lead to material shortages of real goods and services circulating in the national economy, such as food, clothing, and machine parts.

\footnotetext{
5 The absence of a middling group of bourgeois (i.e. a middle class that remained true to its values) divided Spain into two groups of people, the haves and the have nots, the rich and the poor, the powerful and the powerless, which, ultimately bifurcated the country: specifically, between the elite-who cared more about frivolous luxuries and less about managing the country-and underclassmen who vented their rage at being ruled by decadent aristocrats.
} 
In total, all of the economic harms that resulted from the Morisco expulsion prompted royal confessor Antono de Sotomayorto to famously remark: "It is a very short time ago since the Moriscos were expelled—an action which did such harm to these kingdoms that it would be a good idea to have them back again, if they could accept our Holy Faith” (Rawlings, p. 208). Even the Cortes Genrales (the Senate and Congress of Spain) complained "of the great decrease in trade and commerce which has resulted from the expulsion of the Moriscos, because many of them were in business, and they were useful because they tilled the land and worked at other trades, which brought in significant tax revenue, which now ceased” (Dominguez, p. 204). The Conde de Castellar also thought that the Morisco expulsion would mean the ruination of all aspects of the economy. He related this view to King Phillip the II in a 1609 Memorial which said:

The exclusion of the moriscos would be the universal ruin and desolation of this kingdom, [since] the service and usefulness of the moriscos, grounds the food and shelter of all elements of society [in Andalusia] absent which, the incomes of the great aristocrats, the burghers, the ecclesiastics and religious orders, the alms of all the poor, the hospitals and churches, the wages of the mechanical trades, all would disappear, and in consequence the entire kingdom would perish. (Garcia, p. 167)

Objectively speaking, Spain's guiding powers all recognized, at the highest levels, that denying the Moriscos their rightful property then deporting them abroad not only undercut Spain's economy, but also that "failed economic policy [in the form of ethnic cleansing was] failed social policy," as well (Graf, Gresham's Law, p. 189). This universal recognition, in turn, signals that "the modest Moriscos, who work and save, represented the most advanced and potentially the most productive sector of the Spanish economy” (Johnson, p. $61)$.

Evidently, extorting the Moriscos private property causes violence in Don Quixote. For instance, when Ricote's Morisco daughter Ana Felix sails from Algiers to Spain to recover her father's buried treasure "two drunken Ottoman [soldiers aboard her brigantine] shoot two Spanish Navymen” aboard a galleon (p. 919). To avenge his mid-shipmen's manslaughter a Spanish Commodore tries to hang these two Ottomans from the neck until they are dead. But after hearing Ana Felix's back story his superior civil officer relents. He not only allows the Ottoman's to face trial for their crimes (instead of executing them on-the-spot) but also releases Ana Felix by seeing how it "might be arranged for [her] and her father to stay in Spain” (p. 933). This passage shows readers two things: that violence occurs in Don Quixote because Spain stole the Moriscos private property and that characters in the novel (i.e. The Viceroy of Catalonia) start to compensate the Moriscos ${ }^{6}$.

\section{Capitalism's Peaceful Inheritance}

Unlike the fictionalization of Don Quixote's government violently extorting its' Moriscos's private property, the book's pretend state actually enables peace, or at least facilitates non-violence, by allowing its' characters to inherit. For example, Grisostomo inherits "piles of property," (i.e. a landed estate, goods and chattel, cows and horses, sheep and goats, and "heaps of money") (p. 91). Marcela inherits "vast riches" from her father "Guillermo" (p. 92). Antonia Quixana inherits Don Quixote’s estate. The 3 Viedma brothers inherit 3,000 ducats each. Many of the book's other characters inherit movable property, houses, and objects without violent state interference. In Don Quixote, there is no extortionary Marxist Politburo a la Joseph Stalin stating that upon a person's death all the wealth that a producer created during his life must revert to the state for the

\footnotetext{
${ }^{6}$ The compensation of the Moriscos parallels "the economic case made by the Duke of Gandia [and others like him] who claimed [they were] owed compensation for the expulsion of the Moriscos who worked [their] land” (Graf, The Economy of Asses, p. 261).
} 
wellbeing of a utopian community or for the realization of a lofty ideal. Since Cervantes, as author and narrator, does not dramatize a Communist government confiscating and redistributing people's private property he obviates the potential violence associated with characters fighting to keep their merited wealth.

\section{A Medieval Mercedes Then a Modern Salary: Violence Then Peace}

Next, to support elements of Johnson's thesis in Cervantes and the Material World which claims that Don Quixote manifests two "opposing socioeconomic orders" shown by "Don Quixote's devotion to the feudal underpinnings of chivalry," on the one hand, and Sancho's advocacy of capitalism, on the other hand (i.e. "a relationship mediated by money,”) my primary stance, here, is that the book's violence decreases as Don Quixote's Mercedes view of compensation yields to Sancho's wage-based vision of payment (pp. 10-11). To make this argument, then, I will examine what a Mercedes is per se and how this differs from fixed wages.

Mercedes, on the one hand, are royal rewards for services to the Crown consisting of: an official position at court; a hereditary title; houses, lands, vassals; and movable property and captives (i.e. spoils). A salary, on the other hand, is fixed compensation paid regularly (by the day, week, month, or year) for the completion of a particular job not for the fulfillment of a certain service. Unlike a salary, a Mercedes is usually given for winning wars and subjugating one's opponents through violence. A salary, in contrast, is usually earned for finishing peaceful jobs.

Initially, Don Quixote compensates Sancho Panza based on a Mercedes or what we might call largesse. This is why he promises his squire favors for his services such as: a "Governorship of Barataria, foals born of his three mares, [and] 100 gold escudos [that they find in] Cardenio’s travelling bag” (pp. 80, 188, 547). But, later, Don Quixote is forced to create a socioeconomic relationship with Sancho Panza not as a master and servant as in former times, but as a boss and employee, as in modern times. This is why employee Panza negotiates wages for his labor by insisting that his boss, Don Quixote, not only:

settle some fixed wages [on him] that [he'll] pay every month so long as [he] serves [him well, but Sancho Panza also asks that his] wages [be] paid out of [his] regular income, because [he doesn't] want to depend on gifts and favours, [that] come too late, or get damaged on the way, or never arrive at all. (p. 528)

Sancho's insistence, here, on wages, not favors, for his labor shifts the economic base of his relationship with Don Quixote from a master who rewards his servant, at whim, as opportunity dictates, with spoils of victory, to an employer who rewards his employee with small but steady payments. Evidently, Don Quixote agrees to pay Sancho Panza fixed-wages for his labor when he says that since Sancho Panza is: "carrying [his] money [he should] work out how much [he] can and should earn per month, and [to] calculate pro-rata [what he is] owe[d] [so he can be his own] paymaster" (p. 679). Here, it is Don Quixote who sees the value in paying his helper with money, not favors, for his work. Furthermore, since all his life Sancho Panza worked for wages, like when he was "a swineherd, [than] a geese keeper, [later] a steward, [followed by] a country beadle," he is used to receiving cash for his work, not knightly favors for his service (pp. 175, 768, 773). In sum, the changing economic base of Don Quixote and Sancho Panza's friendship (i.e. the passing away of a Mercedes to "the security of an established salary") conveys the book's subtle shift to a capitalistic pay structure (Johnson, p. 29). This economic shift, in turn, leads to altered levels of peace and violence in the book. 
Before Don Quixote and Sancho Panza discuss wages, a salary, and a service fee ${ }^{7}$ they fight hard and often. But after they negotiate fair wages, peace grows. For instance, the connection between a Mercedes and violence is first indicated when Don Quixote tells Sancho Panza that he can "win an island in the twinkling of an eye by serving him as squire, [if he] seize[s] his sword to defend [him, especially if he] see[s] that those who attack [him] are rabble and common people, in which case [he] can most certainly come to [his master's] aid" (pp. 61, 66). Due to this incentive, Sancho Panza "grab[s] a goatherd by the shoulders, flings him down on [a] table [and] pounds [him with his] feet [because this] goatherd leaps upon Don Quixote, seizes him by [the] throat," and tries to throttle him to death (p. 468). Since Sancho Panza thinks he must earn favors from his Lord Quixote by fighting simpletons he repulses assaults against his master. Don Quixote also uses violence to force his will on reality. He threatens to kill Barber Martino for his basin because he thinks he can gain Mercedian war-spoils by bullying people.

Part II of the novel, in contrast, is more peaceful than part I of the book, since Part II takes place after wages are given (i.e. after Sancho Panza earns a modern salary). Textually, this is shown by a variety of calm Part II scenes such as: Don Quixote and Sancho Panza's pacific visit to Toboso to see a purported Dulcinea; our knight's extended stay with Don Diego de Miranda where they discuss poets, poems, and poetry; the Cave of Montesinos episode, where phantasmagorical dream sequences replace the gratuitous violence of part I; long interpolated opinions by Cide Hamete El Benengeli which are philosophical, not gory, in nature. These serene scenes suggest that when Mercedian favors are most obvious violence ensues but when a modern payscale emerges peace prevails.

\section{Contracts, Violence, and Peace}

Another gap in research that needs filling is how the honoring or breach of contracts creates peace or violence in Don Quixote. For example, while Johnson rightly sees a dispute between a farm laborer named Andres and a rich farmer named Juan Haldudo as a management-labor dispute ${ }^{8}$, he does not show how their quarrel is a violent breached contract. I will show that it is.

To begin, consider Andres and Juan's severed pact. Per their sheep herding agreement, Andres and Juan both think they will get what they want from the other: payment, on the one hand, labor, on the other. That in exchange for tending his sheep Andres will earn "seven reals a month," while Juan will have his sheep monitored by a diligent shepherd who ensures that not "a single one of [them] escapes" (p. 43). But when Juan does not pay Andres because Andres violates his contract (since "every day one of [the sheep] goes missing”) one party is out sheep, the other is out payment (p. 42). Because of this breeched contract Juan whips Andres mercilessly, and Andres encourages Don Quixote to use violence to even the score. In brief, the Juan Haldudo/Andres episode highlights the urgent need for contracts to be defined and enforced by judges: not executed by lunatics who whip teenagers for losing sheep, or judged by crazy old men who act like vigilantes because they think they can make their own laws. More largely, this carnage shows readers that when contracts are breached in Don Quixote, parties to that agreement use (or incite) violence due to a perception of unfairness. This is certainly true of Don Quixote's many inn stays when our knight does not pay for his room and board.

\footnotetext{
${ }^{7}$ Sancho Panza's insistence on being paid 825 reals to disenchant Dulcinea by self-flagellating, shows readers that a service fee starts to replace a Mercedes as the ruling economic principle of the book.

${ }^{8}$ See page 7 of Johnson's Cervantes and the Material World for analyses of how Don Quixote's intervention on behalf of little Andres casts him in the role of uninvited arbitrator of a dispute between management and labor.
} 
By contrast, when benevolent characters honor Don Quixote's contracts peace prevails. For example, Don Fernando keeps Don Quixote free by occasionally paying for his inn stays. Father Perez also finances Don Quixote's contracts by "promis[ing] to make good [the innkeeper's] losses as best [he] can-[for] the wineskins and the wine" that Don Quixote destroys (p. 333). This is why he "calms everyone down [by] pay[ing] all the damages (plus interest accruing) for losses sustained [by] Don Quixote” (pp. 333, 347).

In sum, Don Quixote's plot-action shows readers that when contracts are broken violence happens but when contracts are honored peace results.

\section{Capitalism, Social Mobility, and Peace: Earning Money Through Honest Jobs}

Another Capitalist theme in Don Quixote is the concept of a self-made man: the economic individual who flourishes in life by using his mind to earn money.

This new economic man is best illustrated by Sancho Panza's money making motivation (i.e. "his pressing need to get himself out of poverty"), since he is the penniless individual who works hard to achieve some material prosperity (Parr, p. 153). Basically, he is the poor man of ability aspiring to fortune ${ }^{9}$. The ascending individual who can improve his life by being intelligent and working hard. He also represents themes such as economic opportunity and the rise of the able individual. That an able individual can still rise. Sancho Panza also instantiates that "a man can start from modest origins, from small beginnings, [to] rise gradually in the world, as the reward of merit and industry” (Parks, p. 93). Most importantly, Sancho Panza's drive to make money in any way he can illustrates that he "acts like [a] homo-economicus, (i.e. a rational, calculating, profit maximizer)" (Cizakca, p. XXV).

Trader Viedma also embodies “ideals of capitalist enterprise and the self-made man” by showing readers the fundamental goodness of capitalism, where a producer is free to enhance his life and accrue material wealth by earning money honestly (Parks, p. 1). To explain, trader Viedma uses his father's investment of 3,000 ducats "to sail to [south] America [and] buy merchandise" (p. 399). After working hard for many years, he not only enlarges his capital stock by regularly selling his goods to customers ${ }^{10}$; but because of his industry he becomes a wealthy Merchant in Peru who is able to repay his father's loan with interest. This is why Merchant Viedma is the "only true capitalist [of the Viedma family, a] true representative of the new economic order" (Johnson, p. 82).

Similarly, other characters in the novel also work smart-and-hard to better their lives and elevate their social stations, instead of fighting people like delusional Don Quixote does. For example, the book features:

cobblers from Toledo, Millers from Antoquera, farmers from Quintanar, silk merchants from Toledo, cloth-teaslers from Segovia, and needle makers from Cordova. [As well as many] couriers, shepherds, herdsmen, barbers, playwrights, actors, special messengers, farm manageresses, rustic day laborers, town criers, bone setters, corn millers, arms transporters, and lion keepers. (pp. 41, 43, 45, 135 (X 3), 179-180, 258-259, 269, 445, 553, 581, 237, 251 (x 2), 654, 687, 592, 597)

\footnotetext{
9 Since Sancho Panza makes “3, 404 reales with Don Quixote, or over six and three quarters times his normal income,” he represents the idea of the self-made man living in a capitalist society, who climbs from poverty to wealth by means of his own effort (Graf, The Economy of Asses, p. 279).

${ }^{10}$ As Graf explains, "the greatest irony involving commerce in Don Quixote is that the free marketplace rescues the novel from its own violence against itself... since the voluntary exchange of goods and services improves life across the board” (Graf, Five Free-Market Themes in Don Quixote \& Gresham's Law, p. 189). This, then, is why Graf sees commerce as the way to wellbeing.
} 
These people work diligently, in different professions, to enhance their being. They do not fight the authorities (i.e. the Holy Brotherhood) as Don Quixote does. Nor do they try to rob innocent gamblers as a random knife fighter attempts. Rather, they are self-reliant people who advance their lives by making as much honest money as they can. And, since these tradesmen have honest jobs they do not have the will, motive, or time to fight each other. Rather, they only focus on improving their lives through legitimate gains. By contrast, mooches in the novel, like Barataria's knifer, do not work for a living. They rob people who do.

As Johnson says, "one of the cases Sancho Panza is called on to judge [during his governorship of Barataria] involves a winning gambler and a kibitzer (miron), to whom the winner had given an insufficient barato. The miron turns out to be a poor hidalgo, whose nobility, in combination with his poverty transforms him into a parasite with no means of support” (p. 9). Dissatisfied with a tip of four reals, not eight, for helping an unnamed gambler win 1,000 reals, this vagrant tries to rob the gambler for all his winnings. Before he can rob him, though, Sancho Panza arrests him with the words "you without a job or an income, scrounging your way through life on this island, will, tomorrow, leave this [place], under sentence of banishment for ten years" (p. 815). Here, Sancho Panza "shares with [many] political economists a reformist project to replace idleness with productive labor [in Barataria] (i.e. reformers who favor some form of state control to limit charity to the truly needy [and] replace idleness with full employment)" (Johnson, pp. 9, 49). One such economic reformer was Luis de Ortiz " "who wanted everyone, of whatever status, to be required to learn a trade or be exiled" (Johnson, p. 9).

In sum, the fictionalization of a non-welfare state in Don Quixote conveys Cervantes's primary stance that characters in his book who lack a congenital handicap, who are not crippled, and who are not chronically sick, should work to support themselves. ${ }^{12}$

\section{False Connection Between Capitalism and Exploitation}

Some scholars, who write about economics in Don Quixote, mistakenly conflate the book's piracy with the primitive accumulation of capital (like Johnson does). Or erroneously equate the novel's pre-capitalism with Sancho Panza's drive to exploit slaves (like Lukacs does). Or, analyze the story with Marxist rhetoric, as Marxist critics do. I, by contrast, have a different view. I believe that Don Quixote's emerging capitalism should not be linked to piracy, slavery, or collectivism, since the book's true capitalists save their money for a rainy day through individual savings. They do not steal and squander their wealth like pirates do. Nor do they commandeer other people's production by enslaving them.

Thus, to challenge Johnson's claim that Don Quixote manifests a "protocapitalistic system based on piracy and other forms of predation” since, to him, "the [book’s Barbar] corsair economy is organized along capitalist lines” I will briefly analyze characters who legitimately make and save their money (pp. 2, 84, 78). Next, I will disassociate piracy from capitalism. Finally, I will differentiate slave laborers from free workers.

To begin, take the first innkeeper, for example. He “transfigures himself from an 'Andalusian picaroon’ to

\footnotetext{
${ }^{11}$ Luis De Ortiz was a prominent Spanish economist who lived during the second half of the 16th century. Eventually, he became a Castilian treasurer during the reign of King Phillip the II. In 1558 he published a book titled Memorial to the King to Prevent the Export of Money that proposed an economic development plan, which called for the growth of productivity.

12 By "creating the post of overseer of beggars, not for this official to persecute [poor people] but rather to examine [unfortunates] to ensure they are really unable to work," Sancho Panza shows readers that able-bodied, sound-minded men-and-women must labor to flourish in Barataria (838). That only truly handicapped people, individuals who are unemployable through no fault of their own, should depend on the voluntary generosity of others to survive.
} 
a respectable tavern owner” by establishing a road side inn (Gurgen, Don Quixote Explained the Story of an Unconventional Hero, p. 227). Instead of stealing money to survive, he earns money by renting rooms, selling meals, and selling water and feed for horses, mules, and donkeys. Unlike a criminal extortionist he is a proto-capitalist proprietor who does not resemble the immoral pirate predator Johnson describes. Furthermore, producing wealth honestly, saving it wisely, and investing it prudently in kosher businesses, like the innkeeper's inn, for instance, differs markedly from seizing another person's money, spending it quickly, then stealing more money, like the Barbary corsair pirates did.

Thus, to differentiate peaceful capitalism from the violent Barbar economy, I'd like to explore who the Barbary pirates were, how they managed fiscal matters, and what, in essence, their typical method of operation was. Only after understanding this distinction, will you fully understand that capitalism and the Barbary economy are wholly unrelated.

To explain, the Barbary corsairs were four pirate brothers: Oruc, the oldest; Hayreddin (aka Hizir) the youngest; and two less well-known middle brothers. They were nicknamed the Barbarossas (Italian for Redbeard) after Oruc's red beard. Originally from the Levant the Barbarossas operated from the Barbary coast of North Africa, especially from the ports of Algiers, Rabat, Tunis, and Tripoli. Besides seizing ships, the Barbarossa's engaged in Razzias, or raids, on European coastal towns and villages looting gold, jewelry, and coins (i.e. anything of value). In cahoots with the Ottoman Empire, the Barbers were a constant menace to Spain's coastal villages since they conducted sudden land incursions on Iberia, murdering, raping, pillaging, and maiming, Spanish citizens, at whim, as their brutal impulses dictated. Since the Barbary pirates could not sate their unquenchable thirst for booty on the high seas they disembarked on land for more ravaging, more destruction, more mayhem, and more plunder. This continuous Barber marauding prompted Spain, under a succession of monarchs and kings, to build watch-towers along the Andalusian coast and to establish coastguard garrisons $^{13}$. In Africa, the Barbers took full advantage of the Spaniards light presence along a thin coastal supply strip to build pirate strongholds where they safely plotted sea raids on Spain's merchant vessels with relative impunity.

Because the Barbers did not generate honest wealth through productive labor but instead "preferred to consume [their booty] immediately, stimulating the local economy without producing any long-term gain” they did not earn commensurate rewards for legitimate industry (Johnson, p. 79). Rather, they generated wealth by taking it away from someone else. Thus, they were not capitalists like Don Quixote's 3 main innkeepers. Rather they were sponges feeding off others productivity. Ergo, they were part of the nonproductive class out to exploit other people in this world: parasitic forces that undermine a law respecting, private-property worshipping, free-market society. In a word, the Barbers were leeches who siphoned-off the wealth made by truly productive people to appropriate riches for themselves. Draining others' money to survive, these murders do not resemble any true capitalist who did live, is now living, or shall live in the future.

Thus, the predation of the Barbary pirates was not "protocapitalism," or any other form of capitalism, as Johnson suggests. Rather, it was organized crime unconnected to capitalism, period.

\section{Capitalism Does Not Cause Slavery}

A similar confusion propounded by Marxist critiques of Don Quixote is to equate Sancho Panza's

\footnotetext{
${ }^{13}$ The coastguard's protection of Spain's coasts from pirate attack is seen in Don Quixote during the Captive Captain's Tale, when captain Viedma is captured by a coastguard squadron when he lands on the Costa del Sol.
} 
discussion of slavery to Spain's emerging capitalism. To refute this myth, I reason that free workers earning fair wages in a capitalist society is the moral opposite of slave laborers toiling under anti-capitalist slave regimes.

Free workers under capitalism decide where they work, when they work, for whom they work, and how much money they work for, while serfs in a slave society are forced to toil where chance dictates, wherever a random slave master wants them to labor, in exchange for only ameagre subsistence. And, since "serfs [under feudalism] are tied to their Lord's lands [they cannot] move freely and seek work wherever they choose" (Fulcher, p. 30). They cannot self-determine. Rather, they are servile peasants bound by status, unfree to change their social stations or move from their birthplace. This is especially important since "the mobility of capital and labor is one of the [hallmark] features of capitalist societies that gives them their characteristic dynamism" (Fulcher, p. 30). In sum, free workers under capitalism are more productive than slave laborers under serfdom because, unlike slave laborers, free men have a selfish profit motive to work productively ${ }^{14}$.

To elaborate, free workers work hard to: increase the quality, size, and comfort of their homes; elevate the nutrition of their food; increase the durability of their clothing; upsurge the quality of their transport; raise the value of their health care; and grow the excellence of their teachers and schools. Slaves, on the other hand, also want to flourish. But find it nearly impossible to do so, since no matter how smart, hard, and long they work they rarely achieve any lasting gains because what they produce does not belong to them. Ergo, since a slave's labor is robbed by his owner, he is given rags for clothes, gruel for food, flimsy shoes for transport, and shanties for housing. In effect, slave owners break their slave's backs, keep their slaves weak, and exploit their slaves, so their slaves think they must toil or die. Thus, since slaves are made poor, kept poor, ignorant to begin with, and kept ignorant, they are often sick, die young, and are woefully uneducated, shamefully so.

Obviously, slaves live in squalor precisely because they are slaves; because they are not allowed to benefit from their own production. Thus, their production declines, because if a person does not work for himself "he [has] no other interest but to eat as much and to labor as little as possible [since] 'when an individual's output is sundered from his profitability the only logical consequence is diminished productivity”" (Smith, p. 92; Bernstein, The Capitalist Manifesto, p. 461).

Because free workers benefit from their own production; because they can improve their lives by working hard; because they are their own masters, not mastered by other people, they are free to self-actualize. This is why "free workers in pursuit of their own property feel a 'deep interest' in their work, as opposed to the slave who must be forced against his will to do work from which he will [not] benefit” (Fulcher, p. 30). In sum, since free workers living in a libertarian society are treated as dignified human beings (i.e. valuable people) they are free to work hard to improve their lives.

\section{False Connection Between Don Quixote, Capitalism, and Slavery}

Now, to link slavery to Don Quixote, think of Sancho Panza's desire to turn black slaves into yellow gold, not due to greedy capitalism, as some scholars do. But rather as a poor person's desire to become "a feudal noble (i.e. an aristocrat)" as Johnson does (p. 26). Essentially, Sancho Panza wants to "ship [his imaginary] Negro vassals to Spain [for cold,] hard cash" (Cervantes, p. 266). Then, he wants to "buy [him]self a title or some [other] official position [at court], and live at ease for the rest of [his] days” (Cervantes, p. 266). Thus, he

\footnotetext{
${ }^{14}$ By suggesting the harms of slavery in this way, "Cervantes figures the shift from slavery to feudal servitude to modern work for pay” (Graf, The Economy of Asses, p. 278).
} 
wants to steal other people's production to make a quick, easy buck, right away, fast at the expense of another person's freedom. A true capitalist, by contrast, works hard to earn gradual profits over time, after much effort. They do not bully people to get rich quickly.

In brief, the moral of Cervantes discussion of slavery is that a "great leap forward occurs in human society once people realize that paying others for their work is not only more humane, but radically more productive, than compelling them by force” (Graf, The Economy of Asses in Don Quijote, p. 283).

\section{Capitalism Protected: Courts and Judges in Don Quixote Create Peace}

Before connecting Don Quixote's feudal low-justice with violence and Don Quixote's modern objective justice with peace, first some background information on what law courts are for, and what they do, is necessary.

To start, courts are designed "to protect men's property and contracts from breach by force or fraud and to settle [fiscal] disputes according to objectively defined laws” (Rand, p. 43). Thus, courts exist to create and enforce fair economic rules where people behave like rational creatures with logical arguments. In law courts physical force is not used to unfairly enforce a person's economic will over the fiscal volition of another. Rather, reason is used to persuade a judge that a person deserves restitution for an economic breach.

Thus, readers see, in Don Quixote, the beginnings of an autonomous legal system consisting of civil judges, like Sancho Panza, who adjudicate economic disputes dispassionately according to the objective merits of a case.

The objectification of legal cases is first shown when judge Panza arbitrates an economic "disagreement between a farmer, on the one hand, who asks for too many hoods to be made from a single length of cloth, and a tailor, on the other hand, who seems to comply with a farmer's material request only to produce 'five tiny hoods on his fingertips' in court” (Gurgen, Don Quixote Explained the Story of an Unconventional Hero, p. 136). By asking both parties pertinent questions, Judge Panza decides that the tailor will forfeit his pay and the farmer will forfeit his hoods. Here, Sancho Panza gathers facts. Then, he judges. He does not thunder around the countryside attacking people like Don Quixote does. Rather, Judge Panza only adjudicates economic disputes when Barataria's municipal government trusts him to.

But when there are no courts, when laws do not exist, when judges are conspicuously absent violence happens. For example, when Andres and Juan contract over a flock of sheep, there is no legal protocol to resolve their contract. There is only crazy Don Quixote who thinks he is a feudal lord knight judge. If there was a local economic court to address their contractual dispute, the judge could have assigned punitive damages for the whipping. He could have forced Juan Haldudo to pay 73 reals in lost wages for Andres's back-pay. He could have discovered if Andres actually lost Juan's sheep by subpoenaing Juan's farm manager. He could have garnished Andres's wages if he found the lad liable for Juan's lost sheep. He could have jailed Don Quixote for making threats, for enforcing his own laws, for enacting wacky vigilantism. But since there is no judge to determine who is entitled to what and why (i.e. to adjudicate the contract) both parties lose. Juan forfeits real property he needs: the sheep themselves and the sheep's by products he could trade for money. Money he needs to buy more livestock, fix his farm, and buy additional properties. Andres loses money he needs to buy food, pay for clothing, and build shelter. Funds he needs to survive. Without a judiciary both parties are unable to lawfully address their grievances to a neutral third party (i.e. a secular judge who could address and resolve their complaints fairly and peacefully). 


\section{The Holy Brotherhood and Violence/Sancho Panza's Judgeship and Peace}

But before the advent of Spain's modern justice system, Spain's inquisitorial persecutions were extremely gruesome. To explain, without courts the Holy Brotherhood (Santa Hermandad) were the law. Beholden to the crown, "the hermandades (brotherhoods) combined in itself the functions of a police force and a [para-military] judicial tribunal. As a [gendarmerie] its task was to suppress brigandage and to patrol the roads and countryside" (Elliott, p. 87). As a para-military tribunal the Holy Brotherhood "enjoyed complete jurisdiction over certain carefully specified classes of crimes-robbery, murder and arson committed in the open countryside, or in towns and villages when the criminal took to the country, together with rape, housebreaking, and acts of rebellion against the central government” (Elliott, p. 87). In essence, these Alcaldes (mayors) of the Hermandad "reviewed cases, pronounced judgment, and meted out the most savage penalties, which generally consisted of mutilation or a most barbarous death" (Elliott, p. 87). Most importantly, without a police force to arrest and punish criminals the Holy Brotherhood enforces cannon law by a method of "traditional justice where people accused of crimes would often be required to undergo a trial by ordeal in which they would be submitted to some excruciating torture ${ }^{15}$. The ability to withstand it would be seen as a sign from God of their innocence. [But] the more likely and common outcome, [was that] they would succumb to the pain, [which] was taken as a sign of their guilt” (Egginton, p. 143).

Though Spain's early history was marred by the Holy Brotherhood's rife intolerance, Spain's later history was governed by a secular police force that prevented crimes by "adopting a legal system in which witnesses were deposed, statements [were] taken, and sentences [were] imposed [and enforced] in a more systematic, less arbitrary fashion” (Egginton, p. 144). Where, in sum, suspects were given a fair, but stern, civil trial in a law court independent of the monarchy, and were punished, or freed, according to their guilt or innocence, with severity or leniency, as circumstances required.

This is why when Sancho Panza judges cases during his governorship of Barataria he balances reason and fairness, especially when he adjudicates a debt dispute between two old men, where he certifies that: money exchanged hands; repayment was sworn; and the loan's term is over. After certifying that a binding oral agreement was made, Sancho Panza orders the loan to be repaid. He then backs his judgment with a hefty fine and/or jail time for noncompliance. Unlike the Holy Brotherhood violently enforcing King Phillip the III's edicts, on-the-spot, without any trial whatsoever, Sancho Panza peacefully resolves local economic disputes, rationally, by being a municipal Barataria magistrate. This, then, is how Sancho Panza not only links local autonomy with local decision making by fictionalizing "pockets of self-governing at the local level" this is also how he highlights "the right of people to resume the rights of sovereignty they had previously delegated to the King” (Childers, Legal Discourse in Don Quixote, p. 14; Graf, Juan de Mariana and the Modern American Politics of Money, p. 446).

\section{Future Research}

\footnotetext{
15 The range of techniques used to extract people's confessions included garrucha: or suspending a person from the ceiling by his wrists. Then violently pulling his legs, to inflict intense pain, even dislocation. Toca, which consisted of introducing a cloth into the mouth of a victim, and forcing them to ingest water spilled from a jar so that they had the impression of drowning. And potro, or the rack, which is a torture device consisting of a rectangular, usually wooden frame, slightly raised from the ground, with a roller at one or both ends. The victim's ankles are fastened to one roller and the wrists are chained to the other. As the interrogation progresses, a handle and ratchet mechanism attached to the top roller are used to very gradually increase the tension on the chains, inducing excruciating pain.
} 
In conclusion, I hope this journal article shows how capitalism creates peace in Don Quixote while non-capitalism induces violence, so that scholars understand the book better.

Economic topics other Don Quixote scholars can analyze are: how working is promoted during Sancho Panza's island governorship while begging is discouraged and what this means for welfare statism; how the book's primitive barter economy (predicated on swapping goods and services) transitions to a money economy where coined currency governs free-trade; how capitalist accounting practices (i.e. bookkeeping) manifests in the novel (as evidenced by the first innkeeper's ledger) and what this means for Spain's emerging commerce; how Don Quixote symbolizes the financial conflict between the sheep industry, on the one hand, and settled farmers, on the other, and how this conflict fits into Spain's history of pastoral capitalism; how modern finance capitalism is pre-saged in Don Quixote through a variety of financial instruments such as promissory notes, bills of exchange, and fiscal warrants; what the role of Genoese mercantilism in Don Quixote is-especially during the Captive Captain's Tale — and what this meant for Spain's 17th century capital markets; why the influx of precious metals from South America lowered characters living standards and why this is important; what the role of Islamic capitalism in Don Quixote is and what this tells us about 17th century Muslim businessmen; how Capitalist anti-child labor laws, are needed in the little Andres episode, and how this reflects the historic concerns of Spanish labor movements; how free-market competition defines who the economic winners and losers in the art world are, as shown by a variety of good and bad artists in Don Quixote; and, finally, tax-free zones versus taxed areas in Don Quixote and what this means for economic production.

Exploration, of these topics, in Austrian economic terms, may open up a new intellectual path for Cervantine Don Quixote scholars.

\section{References}

Bernstein, A. (2005). The capitalist manifesto: The historic, economic, and philosophic case for Laissez-Fair. Lanham, Maryland: $\mathrm{U} \mathrm{P}$ of America.

Bernstein, A. (2007). Capitalism: The system of the mind. Recorded by the Ayn Rand Institute. CD. Irvine, California.

Bernstein, A. (2004). Global capitalism: The cure for world oppression and poverty. Recorded by the Ayn Rand Institute. DVD. Irvine, California.

Bernstein, A. (1996). Heroism in modern American literature. Recorded by SR Conferences.

Cervantes, M. de. (2000). The ingenious Hidalgo Don Quixote De La Mancha. (J. Rutherford, Trans.). New York: Penguin Books.

Childers, W. (2006). Transnational Cervantes. Buffalo: U Toronto P.

Childers, W. (2005). Legal discourse in Don Quixote. Mester, 1(34).

Cizakca, M. (2011). Islamic capitalism and finance: Origins, evolution, and the future. Massachusetts: Edward Elgar Publishing.

Dominguez, O. A., \& Bernard, V. (1978). Historia de los Moriscos: Vida y tragedia de una minoria. Madrid: Revista de Occidente.

Elliott, J. H. (1988). Imperial Spain: 1469-1716. New York: Penguin Books.

Egginton, W. (1953). The man who invented fiction: How Cervantes ushered in The Modern World. New York: Bloomsbury.

Forester, C. S. (1953). The Barbary Pirates. New York: Random House.

Fulcher, J. (2004). Capitalism: A very short introduction. New York: Oxford UP.

Gurgen, E. (2015). Don Quixote explained: The story of an unconventional hero. 2nd ed. Illinois: Authorhouse.

Gurgen, E. (2014). Don Quixote explained reference guide: Character Encyclopedia, Relationship Dictionary, Theme Reader, Episode Primer, Geographic Atlas, Joke Digest, Latin Translator, and more. Illinois: Authorhouse.

Garcia, A. M. (1975). Los Moriscos. Madrid: Editoria Nacional.

Graf, E. C. (2014). Juan de Mariana and the Modern American Politics of Money: Salamanca, Cervantes, Jefferson, and the Austrian School. The Quarterly Journal of Austrian Economics, 17.4, 442-473.

Graf, E. C. (2015). The economy of asses in Don Quijote de la Mancha: Metalepsis, miscegenation, and commerce in Cervantes's 
Picaresque. ehumanista/Cervantes, 4, 225-288.

Graf, E. C. (2016). Gresham’s Law, Inflation, Price Controls, Subjective Value Theory, and Usury in Miguel de Cervantes’s Don Quixote de la Mancha. In Carmen Garcia de la Rasilla and Jorge Abril Sanchez (Eds.), A Novel without boundaries: Sensing Don Quixote 400 years later (pp. 165-197). Newark, Delaware: Juan de la Cuesta.

Graf, E. C. (2017). Five free-market themes in Don Quijote. Foundation for Economic Education. 22, Oct. 2017. https://fee.org/articles/don-quijote-man-of-free-markets/

Hazlitt, H. (1979). Economics in one lesson: The shortest and surest way to understand basic economics. New York: Random House.

Hutchinson, M. (2012). Early economic thought in Spain: 1177-1740. New York: Routledge Revivals.

Johnson, C. B. (2000). Cervantes and the Material World. Chicago: U Illinois P.

Lambert, F. (2005). The Barbary Wars: American independence in the Atlantic World. New York Hill and Wang Publishing.

Leiner, F. C. (1971). The end of Barbary Terror: America's 1815 war against the pirates of North Africa. Oxford: Oxford UP.

Lukacs, G. (1971). The theory of the novel: A historico-philosophical essay on the forms of Great Epic Literature. (A. Bostock, Trans.). Cambridge: MIT Press.

Parks, L. A. (1996). Studies on themes and motifs in literature: Capitalism in Early American Literature. New York: Peter Lang Publishing.

Parr, J. A. (2003). Review of Carroll B. Johnson's Cervantes and the Material World. Hispanofila, 138, 153-155.

Quint, D. (2003). Cervantes's Novel of Modern Times: A new reading of Don Quixote. Princeton UP.

Rand, A. (1967). Capitalism the unknown ideal. New York: Signet.

Rawlings, H. (2006). The Spanish inquisition. Massachusetts: Blackwell Publishing.

Ridpath, J., Binswanger, H., Chaplin J., \& Clark. J. (2007). Capitalism vs. democratic socialism. Ayn Rand Institute, Irvine..

Schwartz, P. (2007). Back to the dark ages? Today’s attacks on reason and individualism. Irvine, Second Renaissance Books.

Smith, A. (1994). The wealth of nations. New York: Random House.

University of Toronto (Producer). (1984). Debate 1984: Capitalism or Socialism—What is the Moral System? [DVD]. Available https://www.youtube.com/watch?v=aGo2G1Sjb6M

Wood, B. (2012). The battle of reason in the Islamic World and how it was lost. MP3 download. 3 hrs. and 57 mins. 170 MB. 